\title{
Article
}

\section{Leaf Apoplast of Field-Grown Potato Analyzed by Quantitative Proteomics and Activity-Based Protein Profiling}

\author{
Kibrom B. Abreha ${ }^{1, *,+} \oplus$, Erik Alexandersson ${ }^{1}{ }^{\mathbb{D}}$, Svante Resjö $^{1}$, Åsa Lankinen ${ }^{1}$, Daniela Sueldo ${ }^{2, \ddagger}$ \\ Farnusch Kaschani $^{3}$, Markus Kaiser ${ }^{3}$, Renier A. L. van der Hoorn ${ }^{2}$, Fredrik Levander ${ }^{4,5}$ and Erik Andreasson ${ }^{1}$ (D)
}

1 Department of Plant Protection Biology, Swedish University of Agricultural Sciences, SE-234 22 Lomma, Sweden; Erik.Alexandersson@slu.se (E.A.); Svante.Resjo@slu.se (S.R.); Asa.Lankinen@slu.se (Å.L.); Erik.Andreasson@slu.se (E.A.)

2 Plant Chemetics Laboratory, Department of Plant Sciences, University of Oxford, South Parks Road, Oxford OX1 3RB, UK; daniela.sueldo@ntnu.no (D.S.); renier.vanderhoorn@plants.ox.ac.uk (R.A.L.v.d.H.)

3 Chemische Biologie, Zentrum für Medizinische Biotechnologie, Fakultät für Biologie, Universität Duisburg-Essen, Universitätsstr. 2, 45117 Essen, Germany; farnusch.kaschani@uni-due.de (F.K.); markus.kaiser@uni-due.de (M.K.)

4 Department of Immunotechnology, Lund University, SE-221 00 Lund, Sweden; fredrik.levander@immun.lth.se

5 National Bioinformatics Infrastructure Sweden (NBIS), Science for Life Laboratory, Lund University, SE-221 00 Lund, Sweden

check for updates

Citation: Abreha, K.B.;

Alexandersson, E.; Resjö, S.;

Lankinen, Å.; Sueldo, D.; Kaschani, F.; Kaiser, M.; van der Hoorn, R.A.L.; Levander, F.; Andreasson, E. Leaf Apoplast of Field-Grown Potato Analyzed by Quantitative Proteomics and Activity-Based Protein Profiling. Int. J. Mol. Sci. 2021, 22, 12033. https://doi.org/10.3390/ ijms222112033

Academic Editors: Setsuko Komatsu and Sixue Chen

Received: 30 September 2021 Accepted: 2 November 2021 Published: 6 November 2021

Publisher's Note: MDPI stays neutral with regard to jurisdictional claims in published maps and institutional affiliations.

Copyright: (c) 2021 by the authors. Licensee MDPI, Basel, Switzerland. This article is an open access article distributed under the terms and conditions of the Creative Commons Attribution (CC BY) license (https:/ / creativecommons.org/licenses/by/ $4.0 /)$.
* Correspondence: kibrom.abreha@slu.se; Tel.: +4-640-415-000

+ Current address: Department of Plant Breeding, Swedish University of Agricultural Sciences, SE-234 22 Lomma, Sweden.

$\ddagger$ Current address: Department of Biology, Norwegian University of Science and Technology, 5 Hogskoleringen, N-7491 Trondheim, Norway.

\begin{abstract}
Multiple biotic and abiotic stresses challenge plants growing in agricultural fields. Most molecular studies have aimed to understand plant responses to challenges under controlled conditions. However, studies on field-grown plants are scarce, limiting application of the findings in agricultural conditions. In this study, we investigated the composition of apoplastic proteomes of potato cultivar Bintje grown under field conditions, i.e., two field sites in June-August across two years and fungicide treated and untreated, using quantitative proteomics, as well as its activity using activity-based protein profiling (ABPP). Samples were clustered and some proteins showed significant intensity and activity differences, based on their field site and sampling time (June-August), indicating differential regulation of certain proteins in response to environmental or developmental factors. Peroxidases, class II chitinases, pectinesterases, and osmotins were among the proteins more abundant later in the growing season (July-August) as compared to early in the season (June). We did not detect significant differences between fungicide Shirlan treated and untreated field samples in two growing seasons. Using ABPP, we showed differential activity of serine hydrolases and $\beta$-glycosidases under greenhouse and field conditions and across a growing season. Furthermore, the activity of serine hydrolases and $\beta$-glycosidases, including proteins related to biotic stress tolerance, decreased as the season progressed. The generated proteomics data would facilitate further studies aiming at understanding mechanisms of molecular plant physiology in agricultural fields and help applying effective strategies to mitigate biotic and abiotic stresses.
\end{abstract}

Keywords: ABPP; apoplast; proteomics; serine hydrolases; $\beta$-glycosidases; potato; field-omics

\section{Introduction}

In an agricultural field, plants are continuously exposed to varying climate conditions and challenged by mu below- and above-ground microbes, which can trigger morphological and molecular changes. For example, compared to plants grown under greenhouse conditions, Arabidopsis grown in a field displays a different leaf morphology [1] and 
apoplastic proteome profile [2] indicating changes in response to the stresses or variable environmental condition. Therefore, molecular studies performed under laboratory-based conditions investigating response to single stress might not translate directly to field conditions where there are multiple confounding stresses [2,3]. Field experiments are an integral component to test applicability of laboratory-based findings, and they are necessary to solve agricultural challenges (for example, in relation to plant breeding and plant protection). Therefore, field experiments are important to gain basic knowledge about the biology of plant field performance and ecology and to understand the differences in physiology and molecular function of plants growing under field conditions. This is crucial to facilitate applicability of field-based studies (for instance, creating a basis for decision support systems in agriculture based on molecular knowledge) [4].

Potatoes (Solanum tuberosum L.; $2 n=4 x=48$ ), the third most important food crop in the world, are exposed to multiple biotic and abiotic stresses [5]. The plant apoplast is an important arena in plant-microbe interactions [6-8] and plays a crucial role in the plant's response to abiotic stresses [9], as proteins from the plant and the attacking pathogens are secreted into the apoplast $[7,8]$. Apoplastic proteomic studies are crucial to understand defense response against pathogenic microbes $[10,11]$. In potatoes, many proteins in the leaf apoplast change in abundance following the application of host defense inducers $[12,13]$ and P. infestans inoculation [14]. An apoplastic study has also been used for predicting activation of defense response in Solanum species growing under natural and agricultural conditions [15].

Omics techniques have been used in laboratory-based studies to better understand potato response to biotic $[14,16,17]$ and abiotic stresses [18-20]. However, application of these techniques to elucidate the molecular processes in field-grown plants, the so called field-omics approach, is scarce [21]. Label-free quantitative proteomics, based on sensitive and reliable mass spectrometry, has emerged as a powerful tool to investigate plant responses to biotic stress and made it possible to investigate differential abundance of proteins in many different systems $[14,22,23]$. Nevertheless, a change in abundance of a protein identified by quantitative proteomics does not necessarily translate into a change in activity. Recent developments in activity-based protein profiling (ABPP), a method that uses chemical probes that irreversibly bind to the active residue of distinct protein classes in a complex proteome sample, can be used to investigate the functional status of the proteins [24]. This powerful tool has been successfully applied to enhance molecular understanding of different plant-microbe interactions $[25,26]$ and the plant's response to biotic stresses [27]. ABPP is used to determine the activity of certain protein families, including serine hydrolases and $\beta$-glucosidases, in plants challenged by biotic and abiotic stresses [26,27]. Serine hydrolases, carrying an activated serine residue in the catalytic triad, are a large superfamily of enzymes that includes proteases, esterases, lipases, and peptidases $[24,26]$. $\beta$-Glucosidases are glycoside hydrolases that carry a glutamate and aspartate residue at the catalytic site [28]. These enzyme groups are important in cellular processes such as cell wall remodeling, development, biotic and abiotic stress responses. However, to the best of our knowledge, ABPP has not been applied in studies conducted in plants under field conditions.

The objective of this study was to investigate the apoplastic proteome using label-free quantitative proteomics and ABPP to identify apoplastic proteins under field conditions. Therefore, we investigated the apoplastic proteome of field grown potato plants from two different years and followed the change in the abundance of apoplastic proteins during the course of the growing season. Moreover, we performed ABPP on serine hydrolases and $\beta$-glucosidases, to understand the functional state of proteins involved in some biological processes. 


\section{Results and Discussion}

\subsection{Analysis of Apoplastic Peptides}

To get insights into the proteome of field-grown plants, we collected the leaf apoplastic fluid from fully expanded potato leaves of field-grown plants from two field sites over a two-year period. The apoplast is in many cases the first plant compartment that directly interact with the environment and does not contain any dominating protein such as rubisco. Therefore, we chose to analyze this part of the potato proteins under field conditions. The leaf apoplastic fluid was collected using our mobile laboratory $[21,29,30]$ that allows us to isolate, aliquot, and freeze the samples directly on the site, thus reducing the probability of sample degradation, which can be a problem in proteome sampling [31].

In total, we identified 3960 peptides, of which 501 were identical except for the charge differences of the intact peptide precursor ion detected by MS. Average abundance was computed for the identical peptides resulting in 3459 unique peptides, corresponding to 1257 proteins, which were subjected to quantitative analysis. Of the 3459 peptides, 2335 peptides were uniquely identified for a protein in the sequence database. Therefore, they were designated as diagnostic peptides. The use of our assembled RNA-seq data obtained from potato Desirée (cv.), SW93-1015 (breeding line), and Sarpo Mira (cv.) improved peptide identification by $6 \%$ as estimated by the fraction of peptides mapped uniquely to accessions in the RNA-seq data. This increase in peptide identification was however less than the previously reported $17 \%$ [14], maybe due to the fact that we used a different potato cultivar Bintje, not represented in our RNA-seq database used for peptide identification. We identified 85 of the 104 peptides previously reported to be have prediction potential for P. infestans resistance in leaf and tuber, as well as for tuber yield, in the potato clones SW93-1015 and Desirée [32].

Of the 1257 proteins, 419 were predicted to contain a signal peptide as determined by SignalP version 4.1 [33]. This is in line with the previous studies [6,26], where $30-60 \%$ of proteins identified in the apoplast contained a classical signal peptide. Furthermore, Pfam analysis of proteins identified in samples from field-grown plants identified 461 protein families. Peptidases, peroxidases, glycosyl hydrolases, protein GDSL lipases, thaumatin, heat shock proteins, Leucine rich repeat proteins, and epimerases being the predominant protein families in the apoplast of field-grown potato cv. Bintje (Figure 1).

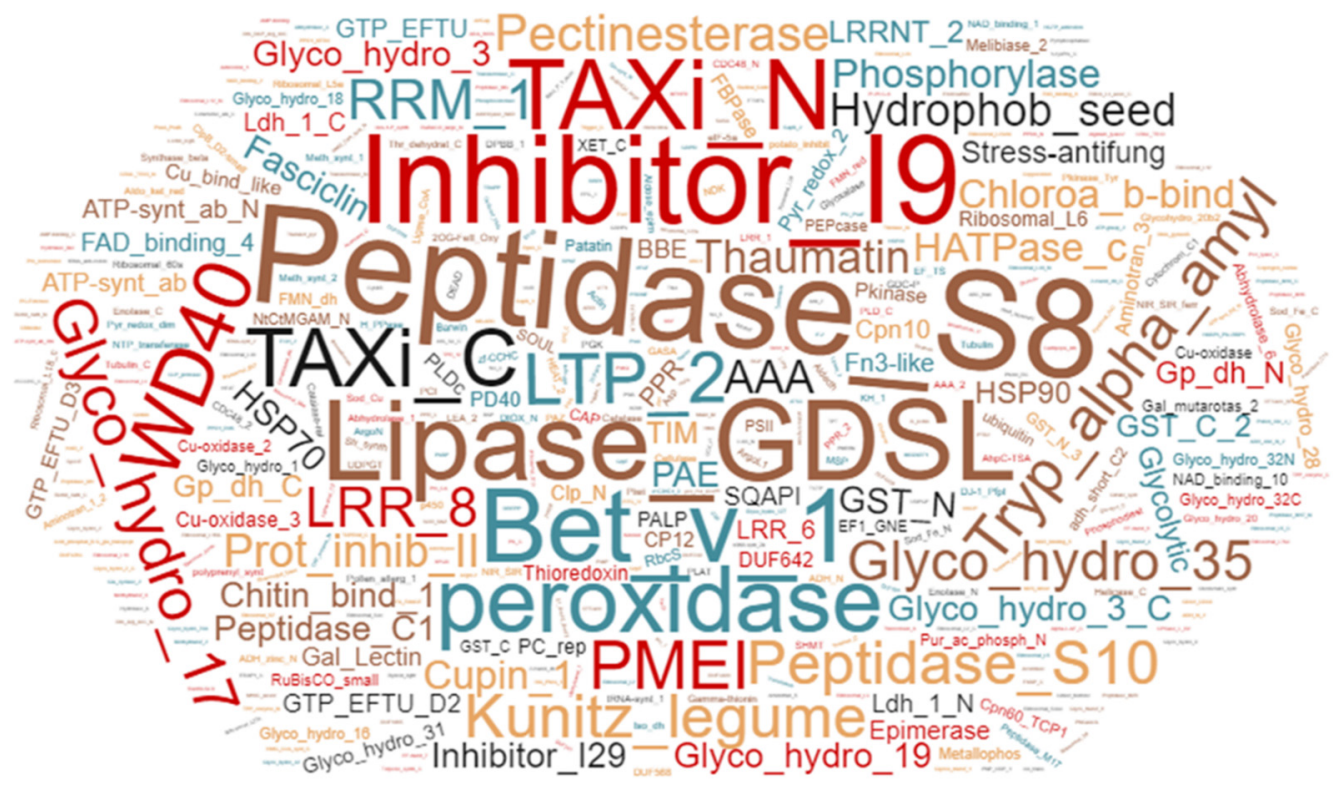

Figure 1. Word-cloud representation of the leaf apoplastic proteome from potato cultivar Bintje. Identified proteins were classified into families using Pfam analysis. Scale of the fonts and colors in the word cloud represents relative abundance of the protein family in the apoplast samples from field-grown plants. 
In our dataset, the correlation between peptide abundance and proportion of samples with missing values was $r^{2}=-0.31$ (Supplementary Figure S1). Such a negative correlation between peptide abundance and missing values is expected and has previously been reported [34].

\subsection{Effect of Fungicide Application on Potato Apoplastic Proteome}

In order to investigate whether the application of a fungicide to control a disease change the abundance of proteins in the apoplast, we compared fungicide treated samples with untreated ones. The fungicide application may directly or indirectly, by changing the microbial communities [35], affect the apoplastic proteome of the plants. Some of the field plants were treated with fungicide Shirlan (classified as non-systemic), targeting foliar and tuber late blight infections in potato. According to the Public Release Summary on the fungicide [36], spraying with $C^{14}$-tagged fluazinam $\left(500 \mathrm{~g} \mathrm{~L}^{-1}\right)$, the active ingredient in Shirlan, revealed small traces of the label in the potato pulp, showing some translocation of the fungicide into the plant. We performed separately two-group comparison ( $t$-test) analysis in Qlucore for 12 samples from 2011 and 18 samples from 2012 in Mosslunda; however, no differentially abundant protein was detected between fungicide-treated and untreated plants in both years in Mosslunda $(q<0.1)$ (data not shown). Therefore, we conclude that the application of fungicide Shirlan did not significantly change the abundance of the apoplastic proteins in potato leaves. Further studies investigating levels and timing of fungicide application, and its translocation and stability in plant tissues would provide crucial insights into its effects on apoplastic proteome.

\subsection{Apoplastic Proteome Differences between Growing Sites and between Years}

To further understand and describe the dynamics of apoplastic proteome in potato leaves growing in field conditions, we compare the data set between the two sites Borgeby in 2010 and in Mosslunda both in 2011 and 2012 growing seasons. The PCA clustered the samples from the two growing sites together (Figure 2A).

Similarly, ref. [2] found an overlap in apoplastic proteome composition of Arabidopsis plants collected from two field sites. It has been shown that the effect of weather conditions on tuber proteome of potato grown at two different fields is minimal [37]. The overlap between field samples observed in the PCA plot indicates the similarity between the apoplastic protein compositions of the potato plants grown in Mosslunda and those grown in Borgeby (Figure 2A). This indicates similar apoplastic proteome profile among the plants grown in these sites. However, a transcriptome analysis of grapevine berries grown in different sites identified more than 8000 differentially expressed genes [38].

To describe individual proteins that were differentially regulated between potato plants grown at these two sites, we performed a two-group comparison ( $t$-test) in Qlucore $(q<0.001)$ and found 314 peptides (9\%) from 234 proteins (Figure 2C). These results indicate that, despite the overlap of Mosslunda and Borgeby samples in the PCA plot, hence similarity in apoplastic proteome, not all of the proteins had a similar pattern of abundance at both growing sites. The abundance of subtilisin-like proteases (Q9LWA4), endochitinase (DMP400046624), Kunitz trypsin inhibitor (DMP400046980), pectinesterase (DMP400055021), and peroxidases (DMP400052953, Q9SD46) were higher in Borgeby plants compared to those grown in Mosslunda and those of glucan endo-1,3- $\beta$-D-glucosidase (DMP400051976), glyceraldehyde-3-phosphate dehydrogenase (DMP400017652), and methionine synthase (DMP400048869) were lower (Supplementary Table S2). 

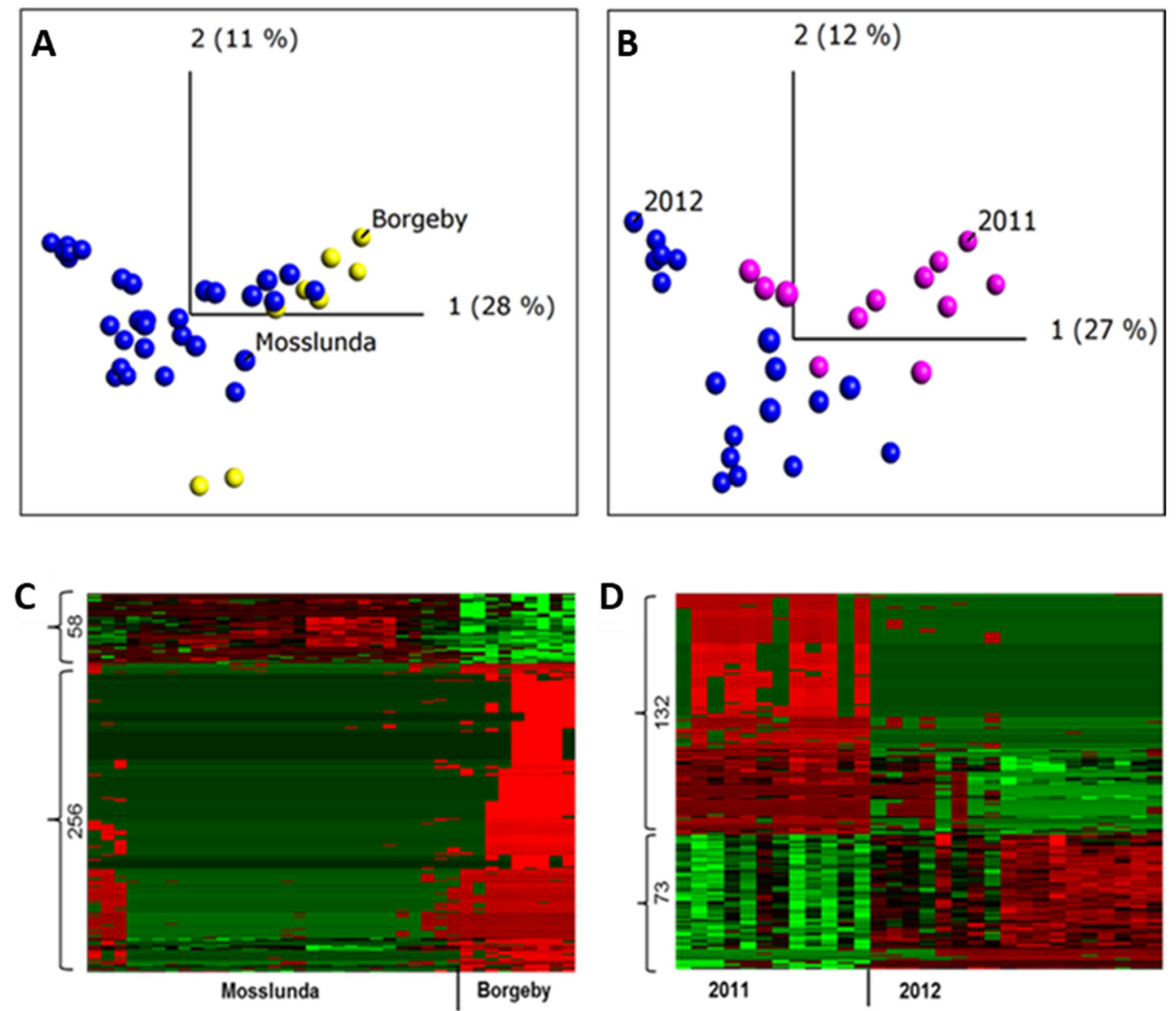

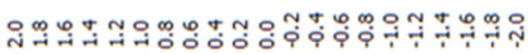

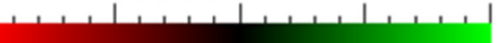

Figure 2. Principal components and heat map analyses of apoplastic proteome samples isolated from potato cultivar Bintje grown at two experimental sites (Borgeby and Mosslunda) and in two different growing seasons (2011 and 2012) in Mosslunda. (A) Unsupervised principal component analysis plot of the samples in Mosslunda and Borgeby; (B) Unsupervised principal component analysis plot of the samples in Mosslunda in 2011 and 2012; (C) Abundance of peptides from Borgeby respectively compared to those in Mosslunda; (D) Abundance of peptides collected in 2011 respectively compared to those collected in 2012 in Mosslunda. Two-group comparisons ( $t$-test) were performed in Qlucore with false discovery rate using Benjamini-Hochberg correction $(q<0.001)$. Heat maps are sorted using hierarchal clustering and red represents higher abundance (Fold change, log2).

Similarly, to investigate the differences between the years, apoplastic samples were collected in 2011 and 2012 from plants grown in Mosslunda. The PCA analysis grouped the samples from the same year together, but there was an overlap between the samples from both years (Figure 2B). A two-group comparison ( $t$-test) analysis in Qlucore $(q \leq 0.001)$ found 205 peptides ( $6 \%$ of total peptides, corresponding to 156 proteins) differentially abundant in 2011 and 2012 in Mosslunda (Figure 2D). This indicates that relatively few apoplastic proteins differ in abundance between the years. Compared to in 2012, osmotin-like protein (Q41350), pectinesterase (DMP400031280), PAE (DMP400041742), polygalacturonase (DMP400021809), and $\beta$-galactosidase (DMP400026688) showed increased abundance in 2011 (Supplementary Table S3). Dal Santo et al. [38] found 625 grapevine genes differentially expressed in at least one of the three growing seasons. Although investigation across more years and locations is required to draw solid conclusions, the result indicates stability of apoplastic proteome profile in potato. It is also possible that, given the sites are in the 
same climate conditions; the variation in weather and biotic condition was minimal thus did not significantly alter the apoplastic proteome.

\subsection{Abundance of Apoplastic Proteins across a Growing Season}

Under field conditions, microbial populations and abiotic stresses change throughout the growing season $[39,40]$ which might accordingly alter the apoplastic proteome profile. To understand the possible changes in the apoplastic proteome within the same growing season, plant samples without disease symptoms collected in June, July, and August in Mosslunda were investigated. The samples from the same month were clustered together, and a multi-group comparison $(q \leq 0.001)$ identified 320 peptides $(9.3 \%)$ from 240 proteins that were differentially regulated in samples collected in at least one of these months (Figure 3A,B).
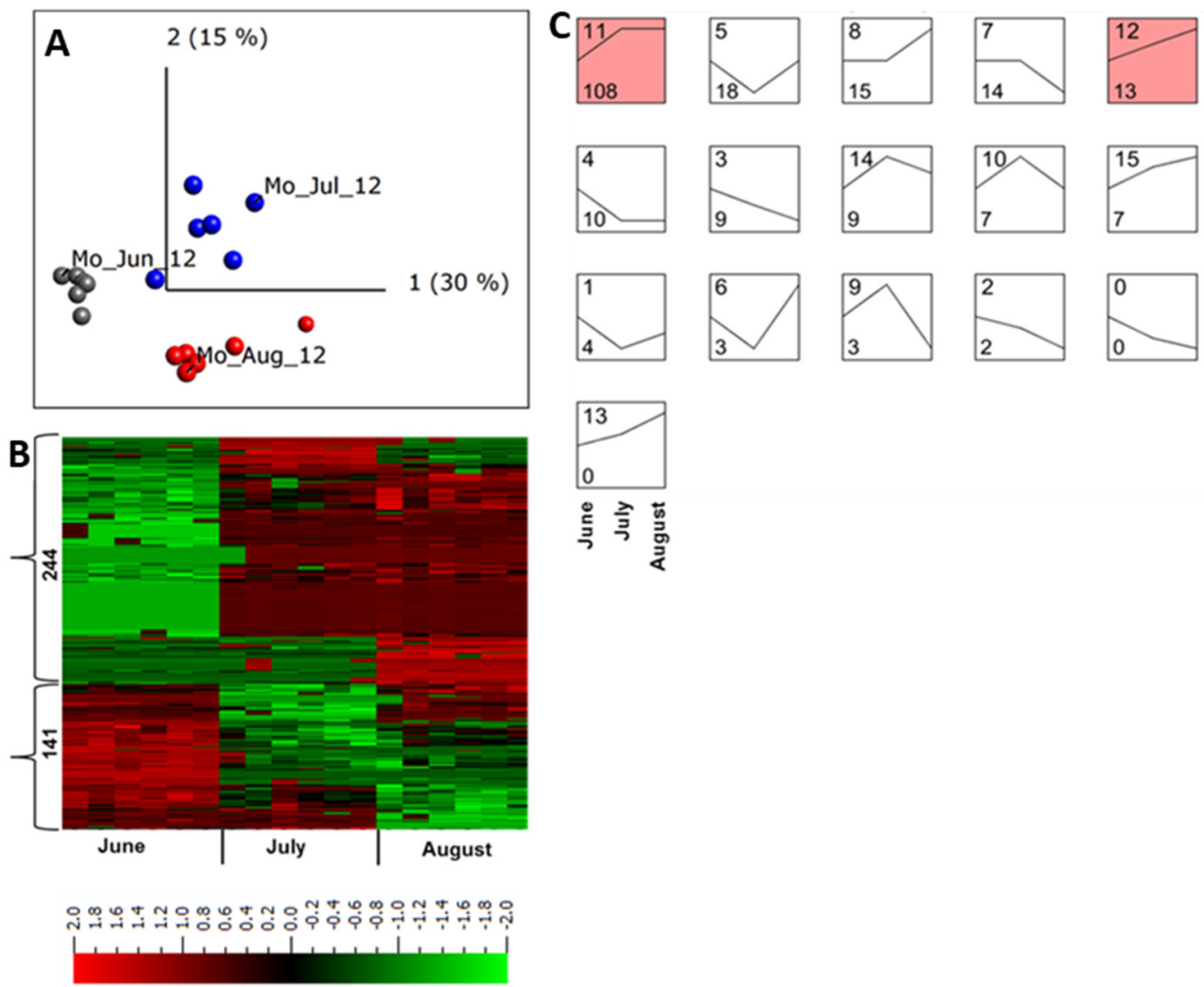

Figure 3. Quantitative analysis of apoplastic proteome samples isolated from potato cultivar Bintje grown in Mosslunda in 2012. (A) Unsupervised principal component analysis plot of all the samples collected in June (Mo_Jun_12), July (Mo_Jul_12), and August (Mo_Jul_12). Each circle represents one biological replicate. (B) Heat maps and the number of peptides up- and down-regulated in plants grown under field conditions in Mosslunda. We performed a multi-group comparison with false discovery rate $<0.001$ (according to the Benjamini-Hochberg procedure for determining $q$ ). Heat map of the differentially regulated peptides $(q<0.001)$ was sorted using hierarchal clustering and red represents higher abundance (Fold change, $\log 2$ ). (C) STEM clustering analysis of apoplastic peptides in June, July, August of 2012 in Mosslunda. Proteins that were significantly $(q \leq 0.001)$ increased or decreased in at least one of the months across the growing season were used for the STEM clustering analysis. Top left of each box is the profile number and bottom left of each box indicates the number of peptides that fit the defined abundance pattern in June, July, and August. The STEM analysis identified 16 profiles, of which profiles 11 and 12 contains statistically significant number of proteins $(p<0.05)$. 
STEM clustering [41] of differentially regulated proteins identified 16 abundance pattern profiles for proteins that were co-regulated throughout the growing season (Figure 3C). Of those, only two were significant profiles $(p<0.05)$. Profile 11 represented proteins with lower abundance in June and their abundance increased at a similar degree in July and August, whereas profile 13 comprised proteins with continued increase in abundance during the season (Figure 3C).

In July and August most of the proteins with increased abundance in profile 11 were involved in plant response to specific biotic and abiotic stresses (Table 1, Figure 3C, profile 11).

Table 1. Differentially abundant proteins in plants collected in June, July, or August in 2012 in fields in Mosslunda at false discovery rate $<0.001$ (according to Benjamini-Hochberg), corresponding to the abundance pattern identified in STEM clustering profile 11 (Figure 3). Only unique peptides were used for the analysis. Shown are peptides with $\log _{2}$ fold change $\geq 4$ in July and August compared to their abundance in June.

\begin{tabular}{|c|c|c|c|c|c|c|}
\hline \multirow[t]{2}{*}{ Peptide Sequence } & \multirow[t]{2}{*}{ Protein IDs } & \multirow[t]{2}{*}{ Protein Name } & Genome & Signal P & \multicolumn{2}{|c|}{ Log2 Fold Change } \\
\hline & & & \multicolumn{2}{|c|}{ Location } & July & August \\
\hline TDPNQNTGIVIQK & DMP400016183 & Pectinesterase & chr03 & Yes & 4.72 & 4.73 \\
\hline DGQPSEQHFGLFYPDQR & Q70BW9 & $\begin{array}{l}\text { 1,3-beta-glucan } \\
\text { glucanohydrolase }\end{array}$ & & & 4.71 & 4.81 \\
\hline GQTWVIDAPR & DMP400005465 & Osmotin & chr08 & Yes & 4.68 & 4.83 \\
\hline GLTWSVPTGR & DMP400022299 & Peroxidase & chr01 & Yes & 4.68 & 4.63 \\
\hline RLDPGQTWVIDAPR & Q5XUH0 & Osmotin-like protein & & & 4.65 & 4.84 \\
\hline MLNEGFVPDDVSLK & Q9FHR3 & $\begin{array}{l}\text { Putative pentatricopeptide } \\
\text { repeat-containing protein } \\
\text { At5g37570 }\end{array}$ & & & 4.65 & 4.56 \\
\hline NIQNAISGAGLGNQIK & DMP400051976 & $\begin{array}{c}\text { Glucan } \\
\text { endo-1,3-beta-D-glucosidase }\end{array}$ & chr10 & Yes & 4.64 & 4.64 \\
\hline TSNLYAIGEMEIEENKK & DMP400023312 & $\begin{array}{l}\text { DUF26 domain-containing } \\
\text { protein } 2\end{array}$ & chr12 & Yes & 4.62 & 4.67 \\
\hline LLALSDTPYK & DMP400046980 & Kunitz trypsin inhibitor & chr06 & Yes & 4.62 & 4.57 \\
\hline VCWPVPNK & DMP400033260 & Xylem serine proteinase 1 & chr10 & No & 4.61 & 4.65 \\
\hline SPSAYLNNPAGER & DMP400007784 & Ceramidase & chr03 & Yes & 4.61 & 4.24 \\
\hline $\begin{array}{l}\text { RYCGMLNVPTGEN- } \\
\text { LDCNNQR }\end{array}$ & DMP400002757 & Class II chitinase & chr02 & Yes & 4.6 & 4.72 \\
\hline $\begin{array}{l}\text { QRCPDAYSYPQDD- } \\
\text { PTSTFTCPSDSTNYR }\end{array}$ & DMP400005463 & Osmotin OSML13 & chr08 & Yes & 4.59 & 4.34 \\
\hline GVIFFGDSPYVFLPGMDVSK & DMP400015799 & $\begin{array}{l}\text { Xyloglucan-specific } \\
\text { endoglucanase } \\
\text { inhibitor } 4\end{array}$ & chr01 & Yes & 4.58 & 4.49 \\
\hline IFESCSTDTFQIR & DMP400041178 & Embryo-specific 3 & chr01 & Yes & 4.57 & 4.51 \\
\hline YCGICCEECK & DMP400037307 & Snakin-1 & chr04 & Yes & 4.57 & 4.45 \\
\hline ALPTYTPESPADATR & DMP400038185 & Transketolase, chloroplastic & chr10 & No & 4.56 & 4.62 \\
\hline VITSSTEAQAYTPGR & Q43143 & $\begin{array}{c}\text { Pectinesterase/pectinesterase } \\
\text { inhibitor U1 }\end{array}$ & & & 4.53 & 4.54 \\
\hline GFEAAPSVSFTVDGEEK & DMP400000884 & Serine carboxypeptidase III & chr11 & No & 4.52 & 4.62 \\
\hline FVVVVDDSK & M1BPR5 & $\begin{array}{l}\text { Uncharacterized protein } \\
\text { (Solanum tuberosum) }\end{array}$ & & & 4.52 & 4.58 \\
\hline AETWVQEETRALISLR & Q43326 & Box II Factor & & & 4.52 & 4.56 \\
\hline KFGLTVDNVLDAR & DMP400031346 & Reticuline oxidase & chr02 & Yes & 4.52 & 4.52 \\
\hline LCPQGGDGGTFANLDK & DMP400055305 & Peroxidase & chr01 & Yes & 4.51 & 4.61 \\
\hline CLCGSPLPDCK & DMP400038422 & $\begin{array}{l}\text { Polygalacturonase inhibitor } \\
\text { protein }\end{array}$ & chr07 & Yes & 4.51 & 4.49 \\
\hline TVTNLGDGQSTYTAK & DMP400027005 & $\begin{array}{l}\text { Subtilisin-like protease } \\
\text { preproenzyme }\end{array}$ & chr12 & Yes & 4.48 & 4.51 \\
\hline LCGEIPKGEYMK & DMP400014905 & $\begin{array}{l}\text { Polygalacturonase inhibiting } \\
\text { protein }\end{array}$ & chr09 & Yes & 4.45 & 4.17 \\
\hline ADNLDTCYR & DMP400025990 & $\begin{array}{l}41 \mathrm{kD} \text { chloroplast nucleoid } \\
\text { DNA } \\
\text { binding protein (CND41) }\end{array}$ & chr08 & Yes & 4.43 & 4.23 \\
\hline
\end{tabular}


Table 1. Cont.

\begin{tabular}{|c|c|c|c|c|c|c|}
\hline \multirow[t]{2}{*}{ Peptide Sequence } & \multirow[t]{2}{*}{ Protein IDs } & \multirow[t]{2}{*}{ Protein Name } & Genome & Signal P & $\log 2$ & Change \\
\hline & & & \multicolumn{2}{|c|}{ Location } & July & August \\
\hline GTGDFTGR & SW_g323.t1 & $\begin{array}{c}\text { Pathogenesis-related } \\
\text { protein } 1 \mathrm{~b} \\
\text { (Solanum tuberosum) }\end{array}$ & & & 4.41 & 4.49 \\
\hline $\begin{array}{l}\text { RIVDIPAGAFSFNSNT- } \\
\text { GAGTIIDSGTVFTR }\end{array}$ & DMP400009572 & $\begin{array}{l}\text { Aspartic proteinase } \\
\text { nepenthesin-1 }\end{array}$ & chr01 & Yes & 4.38 & 4.55 \\
\hline VIIADIQNDLGNSLVK & DMP400032777 & $\begin{array}{l}\text { Short chain alcohol } \\
\text { dehydrogenase }\end{array}$ & chr12 & No & 4.37 & 4.56 \\
\hline TLPESTTNENK & K7WVA0 & $\begin{array}{l}\text { Acyl-CoA-binding protein } \\
\text { (Solanum tuberosum) }\end{array}$ & & & 4.37 & 4.42 \\
\hline CHAVQCTANINGECPGQLK & DMP400023388 & Osmotin & & Yes & 4.35 & 4.68 \\
\hline TNCNFDGDGR & Q01591 & Osmotin-like protein TPM-1 & & & 4.35 & 4.41 \\
\hline LSEDGQVLEVLEDVEGK & DMP400030201 & Strictosidine synthase & chr07 & Yes & 4.31 & 4.59 \\
\hline $\begin{array}{l}\text { SMVGTPLMPGISVDTYIF- } \\
\text { ALYDEDLKPGPGSER }\end{array}$ & DMP400001406 & $\begin{array}{c}\text { Glucan } \\
\text { endo-1,3-beta-glucosidase }\end{array}$ & chr01 & Yes & 4.3 & 4.65 \\
\hline GNLDIFSGR & DMP400035839 & Wound/stress protein & chr04 & Yes & 4.27 & 4.6 \\
\hline ITGNDYSSGVR & DMP400007118 & $\begin{array}{l}\text { Citrate binding protein } \\
\text { Glucan }\end{array}$ & chr11 & Yes & 4.26 & 4.54 \\
\hline AVGEAGLGNDIK & DMP400062364 & $\begin{array}{c}\text { endo-1,3-beta-glucosidase, } \\
\text { basic isoform } 2\end{array}$ & chr01 & No & 4.24 & 4.58 \\
\hline HAGPQFDYLEK & DMP400019521 & $\begin{array}{c}\text { Glutathione S-transferase } \\
\text { omega }\end{array}$ & $\operatorname{chr} 10$ & No & 4.23 & 4.58 \\
\hline SSSTDVFGR & DMP400043338 & Subtilisin-like protease & chr02 & Yes & 4.21 & 4.61 \\
\hline YLVTIGGVEGNPGR & DMP400017956 & Miraculin & chr03 & Yes & 4.21 & 4.52 \\
\hline MYQLSFK & DMP400050666 & Unidentified & chr08 & Yes & 4.21 & 4.48 \\
\hline ADAGHVLVEK & DMP400022826 & MRNA binding protein & chr09 & No & 4.15 & 4.49 \\
\hline GQGTVGTEINR & DMP400023006 & $\begin{array}{l}\text { Threonine dehydratase } \\
\text { biosynthetic, chloroplastic }\end{array}$ & chr09 & No & 4.14 & 4.52 \\
\hline WQPSGADQAANR & P52405 & Endochitinase 3 & & & 4.1 & 4.45 \\
\hline
\end{tabular}

Proteins with increased abundance in July and August included peroxidases (DMP400022299, DMP400055305), serine carboxypeptidase III (DMP400000884), class II chitinase (DMP400002757), pectinesterases (DMP400016183, Q43143), and osmotins (DMP400005465, DMP400005463, Q5XUH0). In addition, ceramidase (DMP400007784), 1,3$\beta$-glucan glucanohydrolase (Q70BW9), glucan endo-1,3- $\beta$-D-glucosidase (DMP400051976), and Kunitz trypsin inhibitor (DMP400046980) also showed increased abundance ( $\log _{2}$ fold change $\geq 4$ ) in July and August compared to that in June (Table 1; Figure 3C, profile 11). This was corroborated by our finding that the number of potato plants with activated immunity increased (as measured as PR protein accumulation) at the end of the growing season, which might be associated with increased presence of pathogens as the season progressed [15].

\subsection{Difference in Protein Abundance under Field and Greenhouse Conditions}

To investigate the apoplastic proteome differences between plants grown under greenhouse and those grown under field conditions, we first conducted an unsupervised PCA. The resulting PCA plot showed a clear clustering of the field- and greenhouse-grown samples into different groups (Figure 4A), regardless of the sampling year and growing site, suggesting distinct apoplastic proteome profiles for field- and greenhouse-grown plants. 

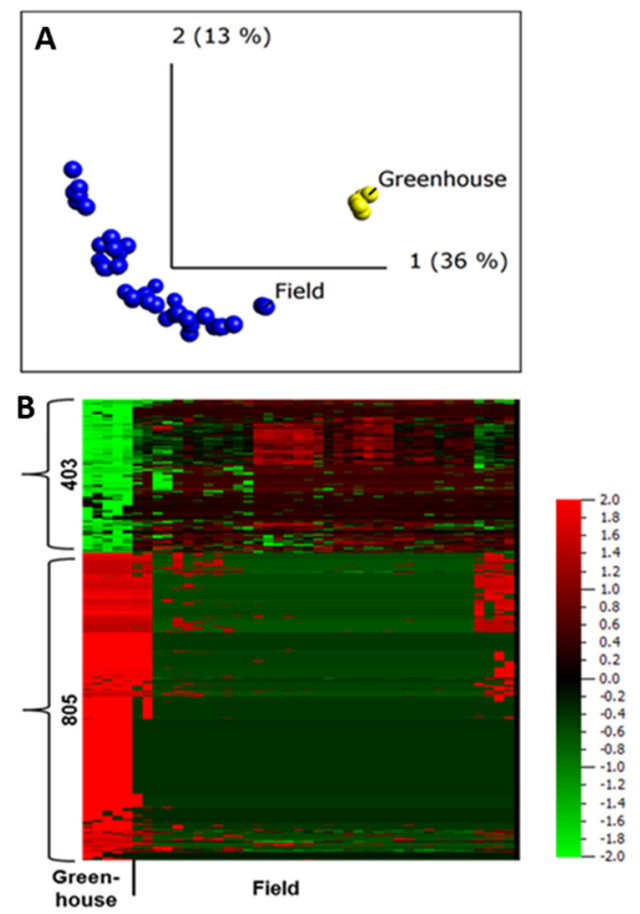

Figure 4. Quantitative analysis of apoplastic proteome samples isolated from potato cultivar Bintje grown under greenhouse and field conditions. (A) Unsupervised principal component analysis plot of all the samples. Each circle represents one biological replicate; (B) heat maps and numbers of peptides up- and down-regulated under greenhouse and field conditions according to a two-group comparison in Qlucore with a false discovery rate $<0.001$ (according to the Benjamini-Hochberg procedure for determining $q)$. The heat map of the differentially regulated peptides $(q<0.001)$ was sorted using hierarchal clustering and red represents higher abundance (Fold change, $\log 2$ ).

This is in agreement with a study that compared apoplastic proteome profiles between field- and laboratory-grown Arabidopsis using a limited number of samples [2]. Our data also strengthens the notion that peptide biomarkers developed using apoplastic proteome of field-grown potato can be a powerful tool for trait prediction [32].

A two-group comparison ( $t$-test) in Qlucore, field vs. greenhouse, identified 1208 peptides that belong to 606 proteins, making up to $48 \%$ of all the proteins identified in the apoplast, to be differentially abundant in plants grown in the field and greenhouse $(q \leq 0.001)$. Of those, 781 peptides were diagnostic, assigned to only one protein in our database. The abundance of 805 peptides was lower in field-grown samples compared to those grown in the greenhouse (Figure 4B). This difference in abundance of most of the proteins in greenhouse samples might be due to differences in extraction efficiency associated with variation in leaf anatomy between plants grown in greenhouse and field conditions [1], or a limited sampling of the greenhouse samples.

To describe the identified proteins that were differentially abundant under field and greenhouse conditions, we carried out a MapMan analysis [42] using 350 differentially abundant proteins with PGSC identity numbers (Supplementary Figure S2). The analysis identified many stress-related proteins such as proteins associated with proteolysis, proteins involved in cell wall synthesis or degradation, proteins classified as pathogenesis-related proteins (PR-proteins), peroxidases, and proteins involved in signaling; most of these proteins were at lower abundance in field-grown plants than in plants grown in the greenhouse (Supplementary Figure S2A). However, most of the redox and heat shock proteins were more abundant in field-grown plants (Supplementary Figure S2B). 


\subsection{ABPP Reveals Seasonal Effects}

Serine and glycosyl hydrolase protein families are commonly found in the apoplast [6]; both families were among the most abundant in our samples (Figure 1). Similarly, we also found that most of the differentially regulated proteins in field-grown plants vs. greenhouse-grown plants were associated with catalytic and hydrolytic activities, as shown using MapMan pathway analysis (Figure 5, Supplementary Figure S2). Therefore, we studied the activity profile of serine hydrolase and $\beta$-glucosidase proteins in the apoplast using ABPP. The labeling of the apoplast for active serine hydrolases identified a signal (\#1) at $100 \mathrm{kDa}$ only in the field-grown potato plants (Figure 5A). In contrast, a signal (\#3) at $40 \mathrm{kDa}$ had higher intensity in greenhouse- than in field-grown plants.
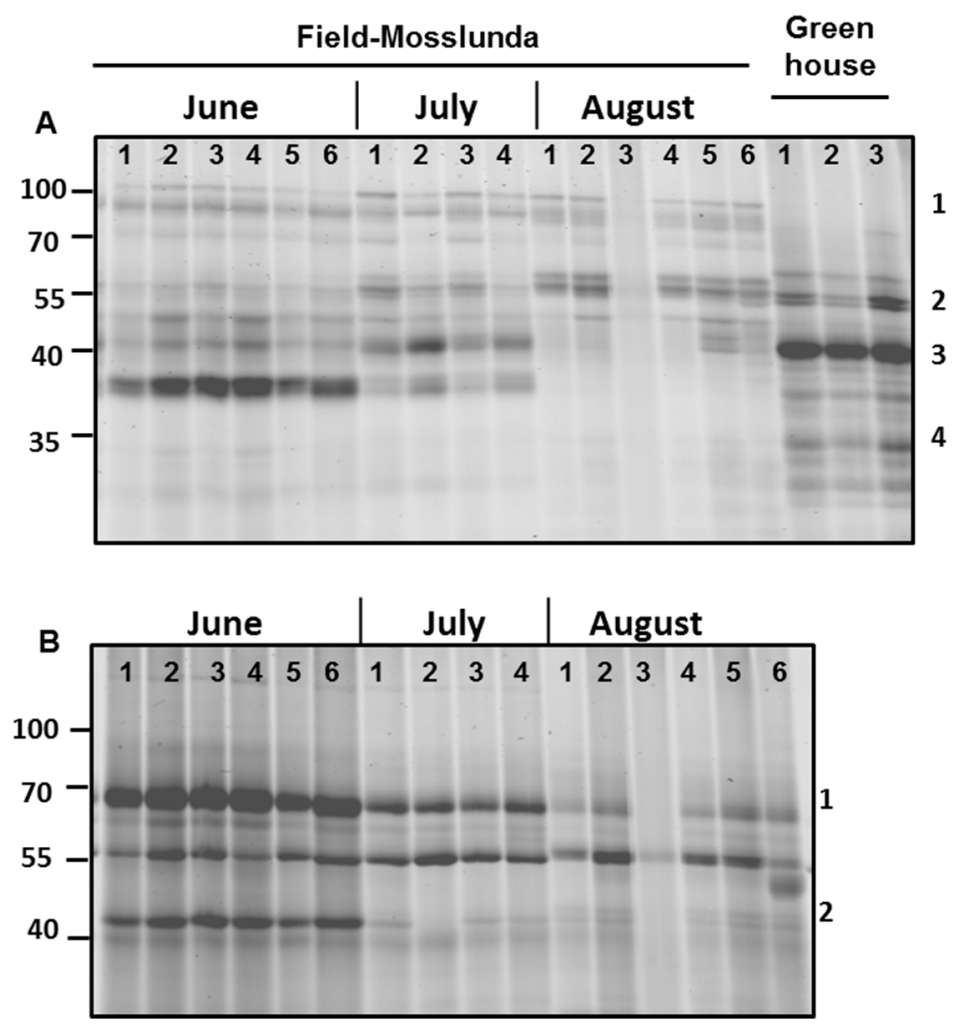

Figure 5. Serine hydrolase and $\beta$-glycosidase activity profiling of potato cultivar Bintje grown under greenhouse and field conditions in Mosslunda in June, July, and August 2012. Apoplastic proteins were labeled by $2 \mu \mathrm{M}$ probe for (A) serine hydrolase and (B) $\beta$-glycosidase. The probe-labelled proteins were separated on $12 \%$ sodium dodecyl sulfate-polyacrylamide electrophoresis gels and detected using a fluorescence scanner.

Surprisingly, we found that the activity of serine hydrolases and $\beta$-glycosidases was generally decreasing as the growing season progressed (Figure 5). The intensity of the signal (\#4) below $40 \mathrm{kDa}$ for active serine hydrolases decreased from June to August in fieldgrown plants (Figure 5A). Using a probe for $\beta$-glycosidases, we identified that intensity signal (\#1) at $70 \mathrm{kDa}$ and signal (\#2) at $40 \mathrm{kDa}$ decreased later in the season (Figure 5B), showing decreasing activity of these proteins as the season progressed.

\subsection{Serine Hydrolases and $\beta$-Glycosidases Identified by ABPP and MS}

ABPP has been applied in a limited number of protein families (van der Hoorn et al., 2011). In this study, to investigate the proteins identified in the activity profile of the potato apoplastic fluid, the samples were purified after labelling with a mix of two biotinylated probes targeting serine hydrolases and $\beta$-glycosidases. The detected protein bands in ABPP were excised and analyzed using MS. The results of the MS analysis of 
the apoplastic proteome, which was used to identify the composition of protein signals, revealed that serine hydrolase signal (\#1) at $100 \mathrm{kDa}$ corresponded to subtilisin-like proteins, such as P69B (DMP400056894), P69E (DMP400007008), P69F (DMP400006964), subtilase (DMP400011990), and serine protease (DMP400006965) (Figure 6).

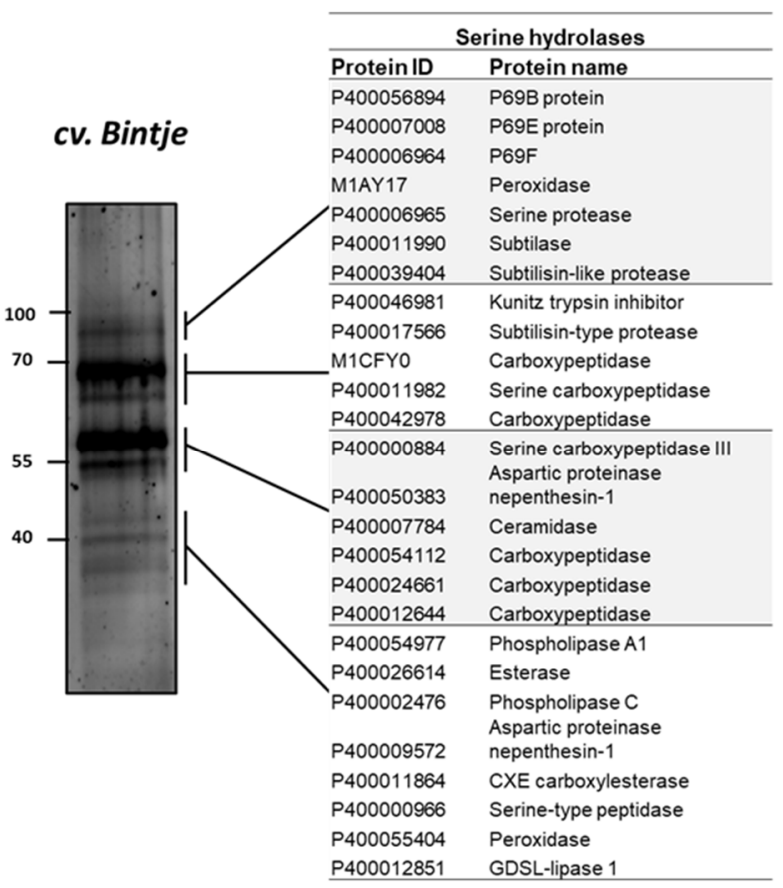

\begin{tabular}{|c|c|}
\hline \multicolumn{2}{|r|}{ GH-Beta glycosidases } \\
\hline Protein ID & Protein name \\
\hline P400004621 & Beta-galactosidase \\
\hline P400010542 & Beta-D-glucan exohydrolase \\
\hline P400015895 & Beta-glucosidase \\
\hline P400016780 & Periplasmic beta-glucosidase \\
\hline P400051976 & Glucan endo-1,3-beta-D-glucosidase \\
\hline P400033415 & Beta-glucosidase 41 \\
\hline P400039774 & Auxin-induced beta-glucosidase \\
\hline P400037552 & Polygalacturonase \\
\hline P400016778 & Periplasmic beta-glucosidase \\
\hline P400009956 & Beta-mannosidase \\
\hline $\begin{array}{l}\text { P400053407 } \\
\text { P400026753 }\end{array}$ & $\begin{array}{l}\text { Glycosyl hydrolase family } 3 \text { protein } \\
\text { Glyceraldehyde-3-phosphate } \\
\text { dehydrogenase }\end{array}$ \\
\hline P400014264 & Beta-galactosidase \\
\hline P400014267 & Beta-galactosidase \\
\hline P400049824 & Alpha-L-fucosidase 2 \\
\hline P400018078 & Alpha galactosidase \\
\hline
\end{tabular}

Figure 6. Identification of serine hydrolases and $\beta$-glycosidases proteins that were captured by activity-based probes. Leaf apoplastic proteome of the potato sample was co-labelled by $5 \mu \mathrm{M}$ biotinylated probes for $\beta$-glucosidase (JJB111) and serine hydrolases (FP-biotin). Biotinylated proteins were then affinity-purified with streptavidin beads and separated on $12 \%$ sodium dodecyl sulfatepolyacrylamide electrophoresis gel. The gel was stained by SYPRO Ruby staining.

Proteins corresponding to signals \#3 and \#4 included carboxylesterase (DMP400011864), esterase (DMP400026614), serine-type peptidase (DMP400000966), and GDSL-lipase 1 (DMP4000-12851) (Figure 6); GDSL-lipase 1 is involved in plant defense against pathogens such as Pseudomonas syringae [43]. Moreover, $\beta$-glycosidases were identified at $100 \mathrm{kDa}(\beta-$ galactosidases [DMP400004621, DMP4000-15895, and DMP400016780]) and at $70 \mathrm{kDa}$ (polygalacturonase [DMP400037552], $\beta$-glucosidase [DMP400033415], $\beta$-mannosidase [DMP400009956]), and $\beta$-galactosidase (DMP400014264 and DMP400014267) and $\alpha$-galactosidase (DMP400018078) were detected at $40 \mathrm{kDa}$ (signal \#4) (Figure 6).

\section{Materials and Methods}

\subsection{Plant Material and Field Sites}

Potato cultivar Bintje was used in this study, and field experiments were conducted at two experimental sites in southern Sweden: Mosslunda ( $\left.55^{\circ} 58^{\prime} \mathrm{N}, 14^{\circ} 6.3^{\prime} \mathrm{E}\right)$ in 2011 and 2012 and Borgeby in $2010\left(55^{\circ} 45^{\prime} \mathrm{N}, 13^{\circ} 23^{\prime} \mathrm{E}\right)$. The experiment site in Borgeby had a sandy clay soil with $2.8 \%$ humus, $16 \%$ clay content, and 55\% fine sand, with pH 7.1. The nutrient concent were Phosphorus (9.9 mg), Potassium (9.9 mg), Magnesium (10 mg), and Calcium (310 mg) per $100 \mathrm{~g}$ soil. In Mosslunda in 2011, the soil was sandy (79\%), with a low clay content $(7 \%)$ and humus $(4.2 \%)$, and the chemical property was $\mathrm{pH}$ was 7.2 , and Phosphorus (31 mg), Potassium (12 mg), Magnesium (13 mg), Calcium (490 mg) per $100 \mathrm{~g}$ of soil. In 2012 in Mosslunda, the soil was sandy (84\%), with a low clay content (3\%) and humus (4.1\%), the $\mathrm{pH}$ was 6.5, and Phosphorus (21 mg/100 g), Potassium (11 mg), Magnesium (10 mg), Calcium (200 mg) per $100 \mathrm{~g}$ of soil. The average temperature, relative 
humidity and precipitation during this study was in Borgeby $\left(17.6^{\circ} \mathrm{C}, 73.8 \% \mathrm{RH}\right.$, and $357 \mathrm{~mm})$, and in Mosslunda in $2011\left(16.9^{\circ} \mathrm{C}, 79.9 \% \mathrm{RH}\right.$, and $\left.293 \mathrm{~mm}\right)$ and in $2012\left(16.0^{\circ} \mathrm{C}\right.$, $78,0 \% \mathrm{RH}$, and $213 \mathrm{~mm}$ ). Furthermore, the monthly weather condition in Mosslunda in 2012 was in June $\left(13.0{ }^{\circ} \mathrm{C}, 76 \% \mathrm{RH}\right.$, and $\left.190 \mathrm{~mm}\right)$, July $(17.1,79 \% \mathrm{RH}$, and $242 \mathrm{~mm})$ and August $\left(17.0^{\circ} \mathrm{C}, 80.0 \% \mathrm{RH}\right.$, and $\left.265 \mathrm{~mm}\right)$. Plants were grown following good experimental practice in accordance with EU directive 93/71, KIFS 2004:4, STAFS 2001:1, and standard operative procedures, SLU 2004 [44]. Plants in the greenhouse were grown at SLU Alnarp $\left(55^{\circ} 65^{\prime} \mathrm{N}\right.$, $\left.13^{\circ} 07^{\prime} \mathrm{E}\right)$, under conditions described previously [44]. Some plants were treated with a fungicide Shirlan (ISK Biosciences Europe S.A., Machelen, Belgium; active ingredient: fluazinam $\left.500 \mathrm{~g} \mathrm{~L}^{-1}\right)$ according to manufacturer's recommendation $\left(0.3 \mathrm{~L} \mathrm{ha}^{-1}\right)$. No pathogen-related symptoms were visible on any of the analyzed leaves.

\subsection{Apoplast Isolation and Protein Digestion}

Apoplastic fluid was isolated, between 10 a.m. and 3 p.m., from five fully expanded leaves of a single plant by vacuum infiltration-centrifugation using a mobile field laboratory as previously described [21,29,30]. Isolated samples were aliquoted on site, frozen in liquid nitrogen, and kept at $-80{ }^{\circ} \mathrm{C}$ until used for either label-free quantitative proteomics analysis or activity-based protein profiling (ABPP). For quantitative proteomics analysis, a $30 \mu \mathrm{L}$ aliquot of each apoplastic sample was cleaned and trypsin-digested as described in [32] before analysis by mass spectrometry.

\subsection{Mass Spectrometry}

For high-performance liquid chromatography-tandem mass spectrometry (HPLCMS/MS) analysis, $5 \mu \mathrm{L}$ of the peptide solution was injected into Eksigent nanoLC-2D HPLC system coupled to a LTQ Orbitrap XL ETD (Eksigent Technologies, Dublin, CA, USA). Peptides were separated using a linear gradient for $90 \mathrm{~min}$ at a flow rate of $300 \mathrm{~nL} \mathrm{~min}^{-1}$. The eluted peptide spectra were acquired, analyzed, and the four most intense ions were selected for fragmentation in linear trap quadrupole (LTQ) [45]. The raw data were converted to mzML [46] and Mascot generic format (MGF) files using ProteoWizard [47] and uploaded to the Proteios software environment (ProSE) [48], where the MGF and mzML files were used for MS/MS identification and feature detection, respectively. Protein identification was performed in Mascot (www.matrixscience.com) (accessed on 1 November 2021) and X!Tandem (www.thegpm.org/tandem) (accessed on 1 November 2021) by searching a protein sequence database containing all Solanum proteins in Uniprot (http: / / www.uniprot.org/) (accessed on 1 November 2021) and potato genome project (https://solgenomics.net/) (accessed on 17 June 2015). Protein sequences based on de novo assembled transcripts of potato clones Desirée, Sarpo Mira, and SW93-1015 were included in the database [14]. Reversed sequences of all the proteins in the database $(449,968$ protein entries) were included as decoys. For MS/MS searches, MS mass tolerance was set to $5 \mathrm{ppm}$ and MS/MS fragment tolerance to $0.5 \mathrm{Da}$. One missed cleavage, fixed cysteine carbamidomethylation, and variable oxidation of methionine were allowed. All search results at the peptide spectrum level were subsequently filtered at a false discovery rate (FDR) of 1\% [48]. Feature detection to quantify peptides was performed on the mzML files from Proteios using Dinosaur [49]. An alignment algorithm was used in Proteios to propagate peptide identities between LC-MS/MS runs [50] and the report was exported for further analysis. After feature matching across all runs with a recall of 0.99 and a precision of 0.80 based on common identifications, the peptide feature level FDR could be estimated to $4 \%$ from the fraction of decoy identifications. The proteomics data used for quantitative analysis have been deposited to the ProteomeXchange Consortium (http:/ / proteomecentral.proteomexchange.org) (accessed on 1 November 2021) via the PRIDE partner repository with the dataset identifier PXD006392. 


\subsection{Quantitative Analysis of Peptides}

The quantitative dataset with peptide precursor intensities was analyzed using Normalyzer v1.1.1 [51], and after comparing 12 normalization methods the Loess-G was used for normalization [52]. The $\log _{2}$-transformed normalized data were used for visualization and statistical tests for identification of differentially abundant proteins; missing values were treated as described in [12]. Qlucore Omics Explorer v3.2 software (http:/ /www.qlucore.se/) (accessed on 1 November 2021) was used to generate principal components analysis (PCA) plots and perform comparative analysis. Unsupervised PCA plots were generated to show similarities or differences between the samples. To identify peptide and proteins with differential abundance, comparative analyses were performed two group comparison ( $t$-test) in Qlucore with the Benjamini-Hochberg false discovery ratio (FDR) procedure $(q \leq 0.001)$. Heat maps sorted with hierarchical clustering were generated and the list of peptide and proteins differentially regulated among the samples was exported for bioinformatics analysis. If the protein was represented by two or more peptides, a median abundance value was calculated.

\subsection{Labelling of Apoplastic Proteome Activity}

For the activity-based profiling, $5 \mu \mathrm{L}$ of $500 \mathrm{mM}$ sodium acetate $(\mathrm{NaAc}, \mathrm{pH}=5)$ and $1 \mu \mathrm{L}$ of $250 \mathrm{mM}$ dithiothreitol (DTT) were added to $43 \mu \mathrm{L}$ of ice-thawed apoplastic fluid. Two micromoles of each probe for serine hydrolases (FP-Rh) [53] and Glycosyl hydrolases (JJB70) [28] were added to the labeling reaction. For the inhibition tests, equal amounts of labeling reactions were pre-incubated for $30 \mathrm{~min}$ at room temperature (RT) with $100 \mu \mathrm{M}$ of inhibitor 3,4 dichloroisocoumarin (DCI) against each probe. In samples without the inhibitor, DMSO was added instead and all labeling reactions were incubated for $1 \mathrm{~h}$ in darkness at RT. The reactions were stopped by adding $15 \mu \mathrm{L}$ of $4 \mathrm{X}$ gel loading buffer, and the whole samples were boiled at $95^{\circ} \mathrm{C}$ for $5 \mathrm{~min}$. Proteins were separated on $12 \%$ sodium dodecyl sulfate-polyacrylamide electrophoresis (SDS-PAGE) gels and probelabelled proteins were detected using a Typhoon 9400 fluorescence scanner (GE Healthcare, Bio-Sciences AB, Uppsala, Sweden).

\subsection{Affinity Purification and Identification of Serine Hydrolases and $\beta$-glycosidases}

Apoplastic fluid of Bintje $(2.5 \mathrm{~mL})$ was incubated with $5 \mu \mathrm{M}$ biotinylated probes for $\beta$-glycosidase (JJB111) [28] and serine hydrolases (FP-biotin) [53], $50 \mathrm{mM} \mathrm{NaAc}$, and $1 \mathrm{mM}$ DTT for $1 \mathrm{~h}$ in the dark at RT. The labelled proteins were affinity-purified as described previously [26,28], eluted from streptavidin beads by adding $30 \mu \mathrm{L}$ of $4 \mathrm{X}$ gel loading buffer and boiling at $95^{\circ} \mathrm{C}$ for $10 \mathrm{~min}$. The samples were centrifuged and $15 \mu \mathrm{L}$ of the supernatant was loaded and separated on $12 \%$ SDS-PAGE gel. The gel was incubated with SYPRO fix for $30 \mathrm{~min}$ and stained overnight in the dark with SYPRO Ruby Protein Gel Stain (Thermo Fischer Scientific, Waltham, MA, USA). Protein bands were detected and excised from the gel using scalpel, and gel pieces were subjected to in-gel tryptic digestion [26,28].

Peptide and protein identification was performed using LC-MS/MS of the in-gel digests on an Orbitrap Elite instrument (Thermo, [54]) that was coupled to an EASY-nLC 1000 liquid chromatography (LC) system (Thermo). The LC was operated in the onecolumn mode. The analytical column was a fused silica capillary $(75 \mu \mathrm{m} \times 36 \mathrm{~cm})$ with an integrated PicoFrit emitter (New Objective) packed in-house with Reprosil-Pur 120 C18-AQ $1.9 \mu \mathrm{m}$ resin (Dr. Maisch). The analytical column was encased by a column oven (Sonation) attached to a nanospray flex ion source (Thermo). The column oven temperature was adjusted to $45^{\circ} \mathrm{C}$ during data acquisition. The LC was equipped with two mobile phases: solvent A ( $0.1 \%$ formic acid, FA, in water) and solvent B $(0.1 \%$ FA in acetonitrile, ACN). All solvents were of UPLC grade (Sigma-Aldrich, St. Louis, MO, USA). Peptides were directly loaded onto the analytical column with a maximum flow rate that would not exceed the set pressure limit of 980 bar (usually around $0.4-0.6 \mu \mathrm{L} / \mathrm{min}$ ). Peptides were subsequently separated on the analytical column by running a $50 \mathrm{~min}$ gradient of solvent A and solvent B (start with 7\% B; gradient 7 to $35 \%$ B for 40 min; gradient 35 to $100 \%$ B 
for $5 \mathrm{~min}$ and $100 \% \mathrm{~B}$ for $5 \mathrm{~min}$ ) at a flow rate of $300 \mathrm{nl} / \mathrm{min}$. The mass spectrometer was operated using Xcalibur software version 2.2 SP1.48. The mass spectrometer was set in the positive ion mode. Precursor ion scanning was performed in the Orbitrap analyzer (FTMS; Fourier Transform Mass Spectrometry) in the scan range of $m / z 300-1500$ and at a resolution of 60,000 with the internal lock mass option turned on (lock mass was 445.120025 $m / z$, polysiloxane) [55]. Product ion spectra were recorded in a data dependent fashion in the ion trap (ITMS) in a variable scan range and at a rapid scan rate. The ionization potential (spray voltage) was set to $1.8 \mathrm{kV}$. Peptides were analyzed using a repeating cycle consisting of a full precursor ion scan $\left(1.0 \times 10^{6}\right.$ ions or $\left.50 \mathrm{~ms}\right)$ followed by 12 product ion scans $\left(1.0 \times 10^{4}\right.$ ions or $\left.100 \mathrm{~ms}\right)$ where peptides are isolated based on their intensity in the full survey scan (threshold of 500 counts) for tandem mass spectrum (MS2) generation. The MS2 permits peptide sequencing and identification. Collision induced dissociation (CID) energy was set to $35 \%$ for the generation of MS2 spectra. During MS2 data acquisition dynamic ion exclusion was set to $60 \mathrm{~s}$ with a maximum list of excluded ions consisting of 500 members and a repeat count of one. Ion injection time prediction, preview mode for the FTMS, monoisotopic precursor selection and charge state screening were enabled. Only charge states higher than 1 were considered for fragmentation.

Peptide and Protein Identification was performed using MaxQuant. RAW spectra were submitted to an Andromeda [56] search in MaxQuant version 1.5.3.30 using the default settings. [57] Label-free quantification was activated. MS/MS spectra data were searched against the Uniprot S. tuberosum (UP000011115_4113.fasta; 53104 entries) [58], as well as assembled RNA-seq datasets of Solanum dulcamara (DUL.fasta; 26392 entries) and Solanum tuberosum cv. Desiree (DES.fasta; 24703 entries) [14,16]. Further analysis and filtering of the results was carried out in Perseus version 1.5.5.3 [59]. Proteins unique or with higher spectral count in a specific protein band in the SDS-PAGE are reported herein. The identified proteins with their spectral counts are listed in Supplementary Table S1.

\subsection{Bioinformatics Analysis}

We used Pfam enrichment analysis [60] for investigation of protein families in the apoplastic proteome. SignalP 4.1 was used to predict the presence of secretion signals in identified proteins [33]. In order to identify proteins with a similar differential regulation pattern, we performed STEM structure analysis in STEM v1.3.8 with default parameters [41]. Location of the identified proteins in potato genome was predicted using SPUD DB Genome browser version 1.70 (http:/ / solanaceae.plantbiology.msu.edu/) (accessed on 1 November 2021). Functional categories of identified proteins were determined by gene ontology (GO) enrichment analysis in agriGO version 2.0 [61]. MapMan version 3.6.0 [42] was used for pathway analysis based on the potato mapping file obtained from GoMapMan [62]. To establish a correlation between the quantitative profiling and ABPP, proteins and peptides found by both approaches were identified based on the sequence similarity analysis. The Potato Genome Sequencing Consortium (PGSC) protein numbers throughout this report have been abbreviated for readability; for example, protein PGSCDMP400044750 is abbreviated to DMP400044750.

\section{Conclusions}

Proteomics can be useful for understanding the physiology of field-grown plants, and we found similarities between years and sites. We show that fungicide may not affect the apoplastic proteome significantly, but this requires a more detailed investigation on the translocation and stability of the fungicide applied and changes in phyllosphere microbial community as well as induction of plant defense responses. Variation in proteomics profile including presence of proteins with differential abundance and activity among samples grown in different sites, growing season, as well as across the months within the growing season indicates dynamic regulation of parts of the apoplastic proteome in response to biotic and abiotic factors. Indeed, most of the differentially regulated proteins were associated with stress related processes. Nevertheless, this warrants further 
investigation to identify proteins that can be useful for molecular-assisted decision making in management strategies of these stresses. The study combines quantitative analysis with ABPP to gain insights into the actual activity of certain protein classes. This study also shows the importance of collecting apoplastic proteomes in field conditions and that understanding the proteome in agricultural fields would be a new dimension in order to understand the physiological state of field-grown plants (field-omics) and support biotic and abiotic stress mitigation strategies.

Supplementary Materials: The following are available online at https:/ / www.mdpi.com/article/10 $.3390 /$ ijms222112033/s1.

Author Contributions: K.B.A., E.A. (Erik Andreasson), Å.L. and F.L. conceived the experiment. K.B.A. collected apoplastic samples, performed ABPP. assays and quantitate proteomics analysis, and drafted the manuscript. S.R. and E.A. (Erik Alexandersson) helped with the quantitative analysis. D.S., F.K., M.K. and R.A.L.v.d.H. supervised the ABPP experiments. All authors have read and agreed to the published version of the manuscript.

Funding: This work was financially supported by Novo Nordisk Foundation, Mistra Biotech, SLF (R-19-25-282), Formas (2020-01211) and European Molecular Biology Organization (EMBO) shortterm fellowship, the ERC starting grant (M.K.; grant No. 258413), ERC Consolidator grant (D.S. and R.A.L.v.d.H., grant No. 616449) and the Deutsche Forschungsgemeinschaft (M.K.; grant No. INST 20876/127-1 FUGG).

Data Availability Statement: The data presented in this study are openly available in ProteomeXchange Consortium at [http:/ / proteomecentral.proteomexchange.org] (accessed on 1 November 2021) with Project DOI: [10.6019/PXD006392] and reference number [PXD006392].

Acknowledgments: We thank Sofia Hydbom and Mia Mogren for their assistance with Apoplast isolation and protein digestion, and Karin Hansson for performing the LC-MS/MS acquisition.

Conflicts of Interest: The authors declare no conflict of interest.

\section{References}

1. Mishra, Y.; Jankanpaa, H.J.; Kiss, A.Z.; Funk, C.; Schroder, W.P.; Jansson, S. Arabidopsis plants grown in the field and climate chambers significantly differ in leaf morphology and photosystem components. BMC Plant Biol. 2012, 12, 6. [CrossRef]

2. Ruhe, J.; Agler, M.T.; Placzek, A.; Kramer, K.; Finkemeier, I.; Kemen, E.M. Obligate Biotroph Pathogens of the Genus Albugo Are Better Adapted to Active Host Defense Compared to Niche Competitors. Front. Plant Sci. 2016, 7, 820. [CrossRef]

3. Poorter, H.; Fiorani, F.; Pieruschka, R.; Wojciechowski, T.; van der Putten, W.H.; Kleyer, M.; Schurr, U.; Postma, J. Pampered inside, pestered outside? Differences and similarities between plants growing in controlled conditions and in the field. New Phytol. 2016, 212, 838-855. [CrossRef] [PubMed]

4. Jones, J.W.; Antle, J.M.; Basso, B.; Boote, K.J.; Conant, R.T.; Foster, I.; Godfray, H.C.J.; Herrero, M.; Howitt, R.E.; Janssen, S.; et al. Brief history of agricultural systems modeling. Agric. Syst. 2016, 155, 240-254. [CrossRef]

5. Oerke, E.C. Crop losses to pests. J. Agric. Sci. 2005, 144, 31. [CrossRef]

6. Alexandersson, E.; Ali, A.; Resjo, S.; Andreasson, E. Plant secretome proteomics. Front. Plant Sci. 2013, 4, 9. [CrossRef]

7. De Wit, P.J. Apoplastic fungal effectors in historic perspective; a personal view. New Phytol. 2016, 212, 805-813. [CrossRef]

8. Jashni, M.K.; Mehrabi, R.; Collemare, J.; Mesarich, C.H.; de Wit, P.J.G.M. The battle in the apoplast: Further insights into the roles of proteases and their inhibitors in plant-pathogen interactions. Front. Plant Sci. 2015, 6, 584. [CrossRef] [PubMed]

9. Song, Y.; Zhang, C.J.; Ge, W.N.; Zhang, Y.F.; Burlingame, A.L.; Guo, Y. Identification of NaCl stress-responsive apoplastic proteins in rice shoot stems by 2D-DIGE. J. Proteom. 2011, 74, 1045-1067. [CrossRef]

10. Delaunois, B.; Jeandet, P.; Clement, C.; Baillieul, F.; Dorey, S.; Cordelier, S. Uncovering plant-pathogen crosstalk through apoplastic proteomic studies. Front. Plant Sci. 2014, 5, 249. [CrossRef]

11. Wang, Y.; Wang, Y.C.; Wang, Y.M. Apoplastic Proteases: Powerful Weapons against Pathogen Infection in Plants. Plant Commun. 2020, 1, 100085. [CrossRef]

12. Bengtsson, T.; Weighill, D.; Proux-Wera, E.; Levander, F.; Resjo, S.; Burra, D.D.; Moushib, L.I.; Hedley, P.E.; Liljeroth, E.; Jacobson, D.; et al. Proteomics and transcriptomics of the BABA-induced resistance response in potato using a novel functional annotation approach. BMC Genom. 2014, 15, 315. [CrossRef] [PubMed]

13. Burra, D.D.; Berkowitz, O.; Hedley, P.E.; Morris, J.; Resjo, S.; Levander, F.; Liljeroth, E.; Andreasson, E.; Alexandersson, E. Phosphite-induced changes of the transcriptome and secretome in Solanum tuberosum leading to resistance against Phytophthora infestans. BMC Plant Biol. 2014, 14, 254. [CrossRef] 
14. Ali, A.; Alexandersson, E.; Sandin, M.; Resjo, S.; Lenman, M.; Hedley, P.; Levander, F.; Andreasson, E. Quantitative proteomics and transcriptomics of potato in response to Phytophthora infestans in compatible and incompatible interactions. BMC Genom. 2014, 15, 497. [CrossRef]

15. Lankinen, A.; Abreha, K.B.; Masini, L.; Ali, A.; Resjo, S.; Andreasson, E. Plant immunity in natural populations and agricultural fields: Low presence of pathogenesis-related proteins in Solanum leaves. PLoS ONE 2018, 13, e0207253. [CrossRef]

16. Frades, I.; Abreha, K.B.; Proux-Wéra, E.; Lankinen, Å.; Andreasson, E.; Alexandersson, E. A novel workflow correlating RNA-seq data to resistance levels of wild Solanum species and potato clones to Phytophthora infestans. Front. Plant Sci. 2015, 6, 718. [CrossRef] [PubMed]

17. Yogendra, K.N.; Kushalappa, A.C. Integrated transcriptomics and metabolomics reveal induction of hierarchies of resistance genes in potato against late blight. Funct Plant Biol. 2016, 43, 766-782. [CrossRef]

18. Evers, D.; Legay, S.; Lamoureux, D.; Hausman, J.F.; Hoffmann, L.; Renaut, J. Towards a synthetic view of potato cold and salt stress response by transcriptomic and proteomic analyses. Plant Mol. Biol. 2012, 78, 503-514. [CrossRef] [PubMed]

19. Gong, L.; Zhang, H.X.; Gan, X.Y.; Zhang, L.; Chen, Y.C.; Nie, F.J.; Shi, L.; Li, M.; Guo, Z.Q.; Zhang, G.H.; et al. Transcriptome Profiling of the Potato (Solanum tuberosum L.) Plant under Drought Stress and Water-Stimulus Conditions. PLoS ONE 2015, 10, e0128041.

20. Boguszewska-Mankowska, D.; Gietler, M.; Nykiel, M. Comparative proteomic analysis of drought and high temperature response in roots of two potato cultivars. Plant Growth Regul. 2020, 92, 345-363. [CrossRef]

21. Alexandersson, E.; Jacobson, D.; Vivier, M.A.; Weckwerth, W.; Andreasson, E. Field-omics-understanding large-scale molecular data from field crops. Front. Plant Sci. 2014, 5, 286. [CrossRef] [PubMed]

22. Zhu, W.H.; Smith, J.W.; Huang, C.M. Mass Spectrometry-Based Label-Free Quantitative Proteomics. J. Biomed. Biotechnol. 2010, 840518. [CrossRef] [PubMed]

23. Liu, Y.H.; Lu, S.; Liu, K.F.; Wang, S.; Huang, L.Q.; Guo, L.P. Proteomics: A powerful tool to study plant responses to biotic stress. Plant Methods 2019, 15, 1-20. [CrossRef] [PubMed]

24. Van der Hoorn, R.A.; Colby, T.; Nickel, S.; Richau, K.H.; Schmidt, J.; Kaiser, M. Mining the Active Proteome of Arabidopsis thaliana. Front. Plant Sci. 2011, 2, 89. [CrossRef] [PubMed]

25. Bozkurt, T.O.; Schornack, S.; Win, J.; Shindo, T.; Ilyas, M.; Oliva, R.; Cano, L.M.; Jones, A.M.E.; Huitema, E.; van der Hoorn, R.A.L.; et al. Phytophthora infestans effector AVRblb2 prevents secretion of a plant immune protease at the haustorial interface. Proc. Natl. Acad. Sci. USA 2011, 108, 20832-20837. [CrossRef]

26. Kaschani, F.; Gu, C.; Niessen, S.; Hoover, H.; Cravatt, B.F.; van der Hoorn, R.A. Diversity of serine hydrolase activities of unchallenged and botrytis-infected Arabidopsis thaliana. Mol. Cell. Proteom. MCP 2009, 8, 1082-1093. [CrossRef]

27. Sueldo, D.; Ahmed, A.; Misas-Villamil, J.; Colby, T.; Tameling, W.; Joosten, M.H.A.J.; van der Hoorn, R.A.L. Dynamic hydrolase activities precede hypersensitive tissue collapse in tomato seedlings. New Phytol. 2014, 203, 913-925. [CrossRef]

28. Chandrasekar, B.; Colby, T.; Emran Khan Emon, A.; Jiang, J.; Hong, T.N.; Villamor, J.G.; Harzen, A.; Overkleeft, H.S.; van der Hoorn, R.A. Broad-range glycosidase activity profiling. Mol. Cell. Proteom. MCP 2014, 13, 2787-2800. [CrossRef]

29. Ali, A.; Moushib, L.I.; Lenman, M.; Levander, F.; Olsson, K.; Carlson-Nilson, U.; Zoteyeva, N.; Liljeroth, E.; Andreasson, E. Paranoid potato: Phytophthora-resistant genotype shows constitutively activated defense. Plant Signal. Behav. 2012, 7, 400-408. [CrossRef]

30. Andreasson, E.; Abreha, K.B.; Resjö, S. Isolation of Apoplast. In Isolation of Plant Organelles and Structures: Methods and Protocols; Taylor, N.L., Millar, A.H., Eds.; Springer: New York, NY, USA, 2017; pp. 233-240.

31. Tyers, M.; Mann, M. From genomics to proteomics. Nature 2003, 422, 193-197. [CrossRef]

32. Chawade, A.; Alexandersson, E.; Bengtsson, T.; Andreasson, E.; Levander, F. Targeted Proteomics Approach for Precision Plant Breeding. J. Proteome Res. 2016, 15, 638-646. [CrossRef]

33. Petersen, T.N.; Brunak, S.; von Heijne, G.; Nielsen, H. SignalP 4.0: Discriminating signal peptides from transmembrane regions. Nat. Methods 2011, 8, 785-786. [CrossRef] [PubMed]

34. Webb-Robertson, B.J.M.; Wiberg, H.K.; Matzke, M.M.; Brown, J.N.; Wang, J.; McDermott, J.E.; Smith, R.D.; Rodland, K.D.; Metz, T.O.; Pounds, J.G.; et al. Review, Evaluation, and Discussion of the Challenges of Missing Value Imputation for Mass Spectrometry-Based Label-Free Global Proteomics. J. Proteome Res. 2015, 14, 1993-2001. [CrossRef]

35. Doherty, J.R.; Botti-Marino, M.; Kerns, J.P.; Ritchie, D.F.; Roberts, J.A. Response of Microbial Populations on the Creeping Bentgrass Phyllosphere to Periodic Fungicide Applications. Plant Health Prog. 2017, 18, 44-49. [CrossRef]

36. Byrnes, C. Public release summary of the evaluation by the NRA of the new active constituent: Fluazinam in the product: SHIRLAN FUNGICIDE. Natl. Regist. Auth. Agric. Vet. Chem. 2011,1-28. Available online: https://apvma.gov.au/node/13751 (accessed on 1 November 2021).

37. Hoehenwarter, W.; Larhlimi, A.; Hummel, J.; Egelhofer, V.; Selbig, J.; van Dongen, J.T.; Wienkoop, S.; Weckwerth, W. MAPA Distinguishes Genotype-Specific Variability of Highly Similar Regulatory Protein Isoforms in Potato Tuber. J. Proteome Res. 2011, 10, 2979-2991. [CrossRef] [PubMed]

38. Dal Santo, S.; Tornielli, G.B.; Zenoni, S.; Fasoli, M.; Farina, L.; Anesi, A.; Guzzo, F.; Delledonne, M.; Pezzotti, M. The plasticity of the grapevine berry transcriptome. Genome Biol. 2013, 14, r54. [CrossRef]

39. Wiik, L. Potato Late Blight and Tuber Yield: Results from 30 Years of Field Trials. Potato Res. 2014, 57, 77-98. [CrossRef] 
40. Zhang, B.; He, H.B.; Ding, X.L.; Zhang, X.D.; Zhang, X.P.; Yang, X.M.; Filley, T.R. Soil microbial community dynamics over a maize (Zea mays L.) growing season under conventional- and no-tillage practices in a rainfed agroecosystem. Soil Till Res. 2012, 124, 153-160. [CrossRef]

41. Ernst, J.; Bar-Joseph, Z. STEM: A tool for the analysis of short time series gene expression data. BMC Bioinform. 2006, 7, 191. [CrossRef]

42. Thimm, O.; Blasing, O.; Gibon, Y.; Nagel, A.; Meyer, S.; Kruger, P.; Selbig, J.; Muller, L.A.; Rhee, S.Y.; Stitt, M. MAPMAN: A user-driven tool to display genomics data sets onto diagrams of metabolic pathways and other biological processes. Plant J. 2004, 37, 914-939. [CrossRef]

43. Kwon, S.J.; Jin, H.C.; Lee, S.; Nam, M.H.; Chung, J.H.; Kwon, S.I.; Ryu, C.M.; Park, O.K. GDSL lipase-like 1 regulates systemic resistance associated with ethylene signaling in Arabidopsis. Plant J. 2009, 58, 235-245. [CrossRef] [PubMed]

44. Liljeroth, E.; Bengtsson, T.; Wiik, L.; Andreasson, E. Induced resistance in potato to Phytphthora infestans-effects of BABA in greenhouse and field tests with different potato varieties. Eur. J. Plant Pathol. 2010, 127, 171-183. [CrossRef]

45. Resjo, S.; Ali, A.; Meijer, H.J.G.; Seidl, M.F.; Snel, B.; Sandin, M.; Levander, F.; Govers, F.; Andreasson, E. Quantitative LabelFree Phosphoproteomics of Six Different Life Stages of the Late Blight Pathogen Phytophthora infestans Reveals Abundant Phosphorylation of Members of the CRN Effector Family. J. Proteome Res. 2014, 13, 1848-1859. [CrossRef]

46. Martens, L.; Chambers, M.; Sturm, M.; Kessner, D.; Levander, F.; Shofstahl, J.; Tang, W.H.; Ropp, A.; Neumann, S.; Pizarro, A.D.; et al. mzML-a Community Standard for Mass Spectrometry Data. Mol. Cell. Proteom. 2011, 10, R110.000133. [CrossRef]

47. French, W.R.; Zimmerman, L.J.; Schilling, B.; Gibson, B.W.; Miller, C.A.; Townsend, R.R.; Sherrod, S.D.; Goodwin, C.R.; McLean, J.A.; Tabb, D.L. Wavelet-Based Peak Detection and a New Charge Inference Procedure for MS/MS Implemented in ProteoWizard's msConvert. J. Proteome Res. 2015, 14, 1299-1307. [CrossRef] [PubMed]

48. Hakkinen, J.; Vincic, G.; Mansson, O.; Warell, K.; Levander, F. The Proteios Software Environment: An Extensible Multiuser Platform for Management and Analysis of Proteomics Data. J. Proteome Res. 2009, 8, 3037-3043. [CrossRef]

49. Teleman, J.; Chawade, A.; Sandin, M.; Levander, F.; Malmstrom, J. Dinosaur: A Refined Open-Source Peptide MS Feature Detector. J. Proteome Res. 2016, 15, 2143-2151. [CrossRef]

50. Sandin, M.; Ali, A.; Hansson, K.; Mansson, O.; Andreasson, E.; Resjo, S.; Levander, F. An Adaptive Alignment Algorithm for Quality-controlled Label-free LC-MS. Mol. Cell. Proteom. 2013, 12, 1407-1420. [CrossRef] [PubMed]

51. Chawade, A.; Alexandersson, E.; Levander, F. Normalyzer: A Tool for Rapid Evaluation of Normalization Methods for Omics Data Sets. J. Proteome Res. 2014, 13, 3114-3120. [CrossRef]

52. Smyth, G.K.; Ritchie, M.; Thorne, N.; Wettenhall, J. LIMMA: Linear models for microarray data. In Bioinformatics and Computational Biology Solutions Using R and Bioconductor. Stat. Biol. Health 2005, 397-420.

53. Kaschani, F.; Nickel, S.; Pandey, B.; Cravatt, B.F.; Kaiser, M.; van der Hoorn, R.A.L. Selective inhibition of plant serine hydrolases by agrochemicals revealed by competitive ABPP. Bioorganic Med. Chem. 2012, 20, 597-600. [CrossRef] [PubMed]

54. Michalski, A.; Damoc, E.; Lange, O.; Denisov, E.; Nolting, D.; Muller, M.; Viner, R.; Schwartz, J.; Remes, P.; Belford, M.; et al. Ultra High Resolution Linear Ion Trap Orbitrap Mass Spectrometer (Orbitrap Elite) Facilitates Top Down LC MS/MS and Versatile Peptide Fragmentation Modes. Mol. Cell. Proteom. 2012, 11. [CrossRef]

55. Olsen, J.V.; de Godoy, L.M.F.; Li, G.Q.; Macek, B.; Mortensen, P.; Pesch, R.; Makarov, A.; Lange, O.; Horning, S.; Mann, M. Parts per million mass accuracy on an orbitrap mass spectrometer via lock mass injection into a C-trap. Mol. Cell. Proteom. 2005, 4, 2010-2021. [CrossRef]

56. Cox, J.; Neuhauser, N.; Michalski, A.; Scheltema, R.A.; Olsen, J.V.; Mann, M. Andromeda: A Peptide Search Engine Integrated into the MaxQuant Environment. J. Proteome Res. 2011, 10, 1794-1805. [CrossRef] [PubMed]

57. Cox, J.; Mann, M. MaxQuant enables high peptide identification rates, individualized p.p.b.-range mass accuracies and proteomewide protein quantification. Nat. Biotechnol. 2008, 26, 1367-1372. [CrossRef]

58. Cox, J.; Hein, M.Y.; Luber, C.A.; Paron, I.; Nagaraj, N.; Mann, M. Accurate Proteome-wide Label-free Quantification by Delayed Normalization and Maximal Peptide Ratio Extraction, Termed MaxLFQ. Mol. Cell. Proteom. 2014, 13, 2513-2526. [CrossRef]

59. Tyanova, S.; Temu, T.; Sinitcyn, P.; Carlson, A.; Hein, M.Y.; Geiger, T.; Mann, M.; Cox, J. The Perseus computational platform for comprehensive analysis of (prote)omics data. Nat. Methods 2016, 13, 731-740. [CrossRef] [PubMed]

60. Finn, R.D.; Coggill, P.; Eberhardt, R.Y.; Eddy, S.R.; Mistry, J.; Mitchell, A.L.; Potter, S.C.; Punta, M.; Qureshi, M.; Sangrador-Vegas, A.; et al. The Pfam protein families database: Towards a more sustainable future. Nucleic Acids Res. 2016, 44, D279-D285. [CrossRef]

61. Du, Z.; Zhou, X.; Ling, Y.; Zhang, Z.; Su, Z. agriGO: A GO analysis toolkit for the agricultural community. Nucleic Acids Res. 2010, 38, W64-W70. [CrossRef]

62. Ramsak, Z.; Baebler, S.; Rotter, A.; Korbar, M.; Mozetic, I.; Usadel, B.; Gruden, K. GoMapMan: Integration, consolidation and visualization of plant gene annotations within the MapMan ontology. Nucleic Acids Res. 2014, 42, D1167-D1175. [CrossRef] 